\title{
F12 Gene
}

National Cancer Institute

\section{Source}

National Cancer Institute. F12 Gene. NCI Thesaurus. Code C104215.

This gene is involved in blood coagulation and fibrinolysis. 